\title{
Military elites and the study of war
}

\author{
MORRIS JANOWITZ
}

University of Michigan

Can war and war-making be seen as a special case of a general theory of social conflict? General theories of social conflict attempt to encompass forms as diverse as family, community, ethnic, and class conflict $(1,3,10)$. Clearly, the understanding of war would be a crucial test of any general theory of social conflict. ${ }^{1}$ Despite aspirations for generalized explanations of social conflicts, social scientists cannot overlook the highly distinctive aspects of war as a process of social change.

First, as of the second half of the twentieth century, wars are "unique" forms of social conflicts because they are waged only by nation-states. War implies social conflict between nation-states with their ideologies for legitimizing the use of violence in the national interest. The nation-state is a territorially based social system which monopolizes the use of the instruments of violence for both internal and external objectives. This is not to exclude from consideration armed conflict between established "imperial" nation-states and revolutionary political groups seeking to establish new and independent nation-states. In the last two decades important political movements of national independence have been able to arm

${ }^{1}$ See Wright (13), esp. chap. xvi, "Scientific Method and the Study of War." themselves. In the process of expelling imperial powers, these revolutionary political movements only create new nation-states which become potential and actual warmakers.

Second, war is differentiated from other forms of social conflict because war-making relies on a highly professionalized and specialized occupation, the professional soldier. By contrast, for example, conflict in the family, in community affairs, and even in wide aspects of economic relations involves no or little specialization of personnel. In these arenas the personnel are the same in conflict and in non-conflict situations. Nevertheless, in most nation-states-totalitarian and democratic - the decision to threaten war or to make war involves "politicians" and "civilian" leaders with broad manipulative skills and not primarily the military professionals. Regardless of the political power of the military elite, the classical forms of absolute military dictatorship are not applicable to a modern mass-industrialized social structure.

Third, the transition from peace to war and from war to peace is determined by a calculus which cannot be found in other types of social conflict. The essential calculus of war-making does not rest on the postulate that any prolongation of peace will increase the probabilities for the further 
prolongation of peace. On the contrary, given the dynamics of the traditional arms race, the prolongation of peace brings with it increased uncertainty about the enemy's war-making potential and therefore may increase the probability of war in order to maintain existing advantages (6). In other forms of social conflict, social inertia and the postponement of decisions may contribute to the non-violent resolution of conflict and differences.

In the language of social science, simple equilibrium models are difficult to apply to the process of war-making. ${ }^{2}$ Instead, a process or developmental analysis which highlights the voluntaristic efforts and calculations of the elites within each nation-state is more appropriate. These considerations lead to the analysis of the organization of political and military elites as a crucial mechanism in the analysis of war and warmaking.

Is it possible to identify different models of political-military elite organization-models which are reflective of different social structures? Can the consequences of the vast technological developments in war-making on the organization of elites be traced out, in order to infer emerging trends? Can important uniformities in the motivational and ideological components of differing political and military elites be established?

\section{Models of Political-Military Elites}

Four models of political-military elites can be identified-aristocratic, democratic, totalitarian, and garrison state. For a base line, it seems appropriate to speak of the aristocratic model of political-military elite structure. The aristocratic model is a composite estimate of western European powers before industrialism began to have its full

2 For a discussion of equilibrium models and social change see Moore (9). impact (12). In the aristocratic model, civilian and military elites are socially and functionally integrated. The narrow base of recruitment for both elites and a relatively monolithic power structure provide the civilian elite with a method of "subjective control" of the military (4).

There is a rigorous hierarchy in the aristocratic model which delineates both the source of authority and the prestige of any member of the military elite. The low specialization of the military profession makes it possible for the political elite to supply the bulk of the necessary leadership for the military establishment. The classical pattern is the aristocratic family which supplies one son to politics and one to the military. Birth, family connections, and common ideology insure that the military will embody the ideology of the dominant groups in society. Political control is civilian control only because there is an identity of interest between aristocratic and military groups. The military is responsible because it is a part of the government. The officer fights because he feels that he is issuing the orders.

In contrast to the aristocratic model stands the democratic one. Under the democratic model the civilian and military elites are sharply differentiated. The civilian political elites exercise control over the military through a formal set of rules. These rules specify the functions of the military and the conditions under which the military may exercise its power. The military are professionals in the employ of the state. They are a small group, and their careers are distinct from the civilian careers. In fact, being a professional soldier is incompatible with any other significant social or political role. The military leaders obey the government not because they believe in the goals of the war but because it is their duty and their profession to fight. Professional ethics as well as democratic parliamentary institutions guar- 
antee civilian political supremacy. The officer fights because of his career commitment.

The democratic model is not a historical reality but rather an objective of political policy. Elements of the democratic model have been achieved only in certain Western industrialized countries, since it requires extremely viable parliamentary institutions and broad social consensus about the ends of government. The democratic model assumes that military leaders can be effectively motivated by professional ethics alone, and this is most difficult. Paradoxically enough, certain types of officers with aristocratic background have made important contributions to the development of the democratic model.

In the absence of a development toward the democratic model, the totalitarian mod$e l$ tends to replace the aristocratic one (11). The totalitarian model, as it developed in Germany, in Russia, and to a lesser degree in Italy, rests on a form of subjective control, as did the older aristocratic model. But the subjective control of the totalitarian model arises not from any natural or social unity of the political and military elites. On the contrary, a revolutionary political elite of relatively low social status and based on a mass authoritarian political party fashions a new type of control of the military elite. The revolutionary elite, bedecked with paramilitary symbols and yet forced into temporary alliance with older military professionals, is dedicated to reconstituting the military elites. Subjective control of the totalitarian variety is enforced by the secret police, by infiltrating party members into the military hierarchy, by arming its own military units, and by controlling the system of officer selection. Under subjective control of the totalitarian variety the organizational independence of the professional military is destroyed. The officer fights because he has no alternative. ${ }^{3}$
The garrison-state model, as offered by Professor Harold D. Lasswell, is the weakening of civil supremacy which can arise even out of an effective democratic structure (7). While the end result of the garrison state approximates aspects of the totalitarian model, the garrison state has a different natural history. It is, however, not the direct domination of politics by the military. Since modern industrial nations cannot be ruled merely by the political domination of a single small leadership bloc, the garrison state is not a throwback to a military dictatorship. It is the end result of the ascent to power of the military elite under conditions of prolonged international tension. Internal freedom is hampered, and the preparation for war becomes overriding. The garrison state is a new pattern of coalition in which military groups directly and indirectly wield unprecedented amounts of political and administrative power. The military retain their organizational independence, provided that they make appropriate alliances with civil political factions. The officer fights for national survival and glory.

It cannot be assumed that all forms of militarism involve "designed militarism." "Designed militarism"-the type identified with Prussian militarism-involves the modification and destruction of civilian institutions by military leaders acting directly and premeditatedly through the state and other institutions. Equally significant and more likely to account for crucial aspects of the garrison state, as well as for contemporary American problems, is "unanticipated mili-

3 The totalitarian model which developed in western Europe is not the same as the survival of feudal-like military dictatorship still found in parts of South America, in which a military junta directly dominates civilian military life. The Perón model was a strange combination of the old-style military dictatorship plus the newer devices of the totalitarian model. 
tarism." "Unanticipated militarism" develops from a lack of effective traditions and practices for controlling the military establishment, as well as from a failure of civilian political leaders to act relevantly and consistently. Under such circumstances a vacuum is created which not only encourages an extension of the tasks and power of military leaderships but actually forces such trends.

The threats to the democratic model cannot be meaningfully analyzed merely from the point of view of "designed militarism." "Designed militarism" emphasizes the impact of military leadership on the civil social structure. "Unanticipated militarism" requires an analysis of the manner in which the military profession responds and reacts to the developments in civilian society. The technology of war, which is the advanced technology of civilian society, lies at the root and sets the preconditions in the trends toward "unanticipated militarism."

\section{Consequences of Technological Trends}

The long-term technological development of war and war-making required the professionalization of the military elite. Such technological developments were compatible with the democratic model of political-military elites, since this model rests on the differentiation of the functions of politicians and soldiers. However, the current continuous advance in the technology of war begins to weaken the possibility of the democratic elite model.

The vast proliferation of the military establishments of the major industrialized nations is a direct consequence of the continuous development of the technology of warfare. The "permanent" character of these vast military establishments is linked to the "permanent" threat of war. It is well recognized that under these conditions the tasks which military leaders perform tend to widen. Their technological knowledge, their direct and indirect power, and their heightened prestige result in their entrance, of necessity, into arenas which have in the recent past been preserved for civilian and professional politicians. The result is the tremendous stress on the traditional assumptions about the effectiveness of the democratic model for regulating political-military relations. The need that political leaders have for active advice from professional soldiers about the strategic implications of technological change serves only to complicate the task of redefining spheres of competence and responsibility. Totalitarian, as well as democratic, nations are faced with these problems.

The impact of the technological development of warfare over the last half-century leads to a series of propositions about social change:

A larger percentage of the national income of modern states is spent for the preparation, executing, and repair of the consequences of war.

There is more nearly total popular involvement in the consequences of war and war policy, since the military establishment is responsible for the distribution of a larger share of civilian values and since the destructiveness of war has increased asymptotically.

The monopolization of legal armed violence held by the military has increased so greatly that the task of suppressing internal violence has declined, as compared with the external tasks of the national security (2).

The rate of technological change has become accelerated, and a wider diversity of skill is required to maintain the military establishment.

The previous periodic character of the military establishment (rapid expansion, rapid dismantlement) has given way to a more permanent maintenance or expansion. 
The permanent character of the military establishment has removed one important source of political-military conflict, i.e., the civilian tendency to abandon the military establishment after a war. Instead, because of the high rate of technological change, internal conflicts between segments of the military elite have been multiplied.

The diversification and specialization of military technology have lengthened the time of formal training required to acquire mastery of military technology, with the result that the temporary citizen army will become less important and a completely professional army more vital.

The complexity of the machinery of warfare and the requirements for research, development, and technical maintenance tend to weaken the organization line between the military and the non-military.

Because of these technological and largescale administrative developments, civilian society as well as the military establishment is undergoing basic transformation. The contemporary tension in political-military organization within the major industrialized powers has a common basis to the degree that the technological requirements of war are highly universal. Yet the differences in the amount or character of political power exercised by military leaders and the methods for resolving conflicts between political and military leaders as between the major nation-states cannot be explained primarily or, even to any great extent, by differences in the technological organization of their armed forces. This is not to deny that each weapon system-land, sea, or naval-tends to develop among its military managers characteristic orientations toward politics based on the technical potentialities of their weapons. The political outlook of any military establishment will be influenced by whether it is an organization dominated by army, navy, or air force. Nevertheless, tech- nological developments merely set the limits within which the civilian and military elites will share power. National differences in the influence patterns of military elites must be linked to national differences in social structure and elite organization.

These technological trends in war-making have necessitated extensive common modification in the military profession in both democratic and totalitarian systems and regardless of national and cultural differences. The changes in the military reflect organizational requirements which force the permanent military establishment to parallel other civilian large-scale organizations. As a result, the military takes on more and more the common characteristics of a government or business organization. Thereby, the differentiation between the military and the civilian-an assumed prerequisite for the democratic elite model-is seriously weakened. In all these trends the model of the professional soldier is being changed by "civilianizing" the military elite to a greater extent than the "militarizing" of the civilian elite.

What are some of these modifications in the military profession? They include $(a)$ "democratization" of the officer recruitment base, (b) a shift in the basis of organization authority, and (c) a narrowing of the skill differential between military and civilian elites. Propositions concerning these trends for the United States military during the last fifty years are applicable in varying form to the military establishment of the other major industrialized nations (5).

\section{a) “Democratization" of the OFFICER RECRUITMENT BASE}

Since the turn of the century the top military elites of the major industrialized nations have been undergoing a basic social transformation. The military elites have been shifting their recruitment from a narrow, 
relatively high-status social base to a broader, lower-status, and more representative social base.

The broadening of the recruitment base reflects the demand for large numbers of trained specialists. As skill becomes the basis of recruitment and advancement, "democratization" of selection and mobility increases. This is a specific case of the general trend in modern social structure of the shift from criteria of ascription to those of achievement. In western Europe the "democratization" of the military elites displaced the aristocratic monopoly of the officer corps; in the United States an equivalent process can be observed, although social lines are generally less stratified and more fluid. The sheer increase in size of the military establishment contributes to this "democratization." The United States Air Force, with its large demand for technical skill, offered the greatest opportunity for rapid advancement.

From the point of view of the democratic model, "democratization" of social recruitment of military leaders is not necessarily accompanied by "democratization" of outlook and behavior. By "democratization of outlook and behavior" is meant an increase in accountability or an increase in the willingness to be accountable. In fact, the democratization of the military profession carries with it certain opposite tendencies. The newer strata are less aware of the traditions of the democratic model. Their opportunities for mobility make them impatient and demanding of even greater mobility. Their loyalty to the military establishment begins to depend more and more on the conditions of employment rather than on the commitment to the organization and its traditions.

The increased representativeness of social background of the military profession also results in an increased heterogeneity of the top leaders within the various military serv- ices. Under these conditions it is more diffcult to maintain organization effectiveness and at the same time enforce the norms of civilian political control. (In a totalitarian society, it likewise becomes more difficult to maintain organization effectiveness and enforce party loyalty.) Of course, any largescale organization develops devices for overcoming these forms of disruption. The military profession emphasized honor as a unifying ideology, and intra-service marriage patterns have been a power device for assimilating newcomers into the military establishment. But requirements of bureaucratic efficiency corrode honor, and the military marriage, like civilian marriage, is currently more limited in its ability to transmit traditions.

Even more fundamental, the new "democratization" changes the prestige position of the military profession. The older traditional soldier has his social prestige regulated by his family of origin and by the civilian stratum from which he came. What society thought was of little importance as long as his immediate circle recognized his calling. This was true even in the democratic model. The British officer corps, with its aristocratic and landed-gentry background and its respectable middle-class service families, is the classic case in point. In varying degrees before World War II it was true for the United States Navy, with its socialite affiliations, and even the United States Army, with its southern military family traditions. But with democratization of the profession, the pressure develops for prestige recognitions by the public at large. A public relations approach must supplant a set of personal relations. Public relations becomes not merely a task for those specialists assigned to developing public support for military establishment policies. Every professional soldier, like every businessman or government official, must represent his es- 
tablishment and work to enhance the prestige of the professional military. In turn, a military figure becomes a device of enhancing a civilian enterprise. Under these circumstances, objective control gives way to subjective identity.

\section{b) SHIFT IN THE BASIS OF ORGANIZATION AUTHORITY}

It is common to point out that military organization is rigidly stratified and authoritarian in character because of the necessities of command. Moreover, since military routines are highly standardized, it is generally asserted that promotion is in good measure linked to compliance with existing procedures and existing goals of the organization. (These characteristics are found in "civilian" bureaucracies but supposedly not with the same high concentration and rigidity.) Once an individual has entered into the military establishment, he has embarked on a career within a single pervasive institution. Short of withdrawal, he thereby loses the "freedom of action" that is associated with occupational change in civilian life.

From such a point of view, the professional soldier is thought to be authoritarian in outlook. Status and the achievement of status are thought to be fundamental motivations. The organizing principle of authority is domination-the issuing of direct commands. The professional soldier is seen as limited in his ability and skill to participate in "civilian" political affairs which require flexibility, negotiation, and the "art of persuasion."

However, it is not generally recognized that a great deal of the military establishment resembles a civilian bureaucracy as it deals with problems of research, development, supply, and logistics. Even in those areas of the military establishment which are dedicated primarily to combat or to the maintenance of combat readiness, a central concern of top commanders is not the enforcement of rigid discipline but rather the maintenance of high levels of initiative and morale. This is a crucial respect in which the military establishment has undergone a slow and continuing change since the origin of mass armies and rigid military discipline (8).

Initiative rather than the enforcement of discipline is a consequence of the technical character of modern warfare, which requires highly skilled and highly motivated groups of individuals. Often these formations must operate as scattered and detached units, as opposed to the solid line of older formations. It is also a consequence of the recruitment policies of modern armies, which depend on representative cross-sections of the civilian population rather than on volunteers. Modern armies increasingly draw their recruits from urbanized and industrialized populations and less from illiterate agricultural groups, for whom response to discipline is a crucial and effective form of control. Tolerance for the discomforts of military life decreases. The "rationality" and skeptism of urban life carry over into military institutions to a greater degree than in previous generations. The rationalization of military life makes necessary the supplying of more explicit motives. Social relations, personal leadership, material benefits, ideological indoctrination, and the justice and meaningfulness of war aims are now all component parts of morale.

Short of complete automation, specialized units manning the crucial technical instruments of war must display fanatically high morale in order to achieve successful military offensive action. Although military formations are still organized on the basis of dicipline, military command involves an extensive shift from domination to manipulation as a basis of authority. Manipulation implies persuasion, negotiation, and expla- 
nation of the ends of the organization. Direct orders give way to the command conference. Since manipulation involves high social interaction, differences in status are tempered by morale objectives. Shifts from domination to manipulation, from status to morale, are present in many aspects of civilian society. However, the peculiar conditions of combat have obscured the extent to which morale leadership is especially required for military formations. This is not to imply that the military establishment has found a formula for approximately balancing domination and manipulation.

\section{c) NARROWING THE SKILL DIFFERENTIAL} BETWEEN MILITARY AND CIVILIAN ELITES

The consequences of the new tasks of military management imply that the professional soldier is required more and more to acquire skills and orientations common to civilian administrators and even political leaders. $\mathrm{He}$ is more interested in the interpersonal techniques of organization, morale, negotiation, and symbolic interaction. $\mathrm{He}$ is forced to develop political orientations in order to explain the goals of military activities to his staff and subordinates. Not only must the professional soldier develop new skills necessary for internal management; he must develop a "public relations" aptitude, in order to relate his formation to other military formations and to civilian organizations. This is not to imply that these skills are found among all the top military professionals, but the concentration is indeed great and seems to be growing. The transferability of skills from the military establishment to civilian organizations is thereby increased. Within the military establishment, conflicts occur and deepen with greater acceleration between the old, traditionally oriented offcers and the new, who are more sensitized to the emerging problems of morale and initiative.

\section{Trends in Indoctrination}

In the past, institutional indoctrination of the military professional in the United States avoided discussion of human factors in the military establishment and the political consequences of military operations. (It is, of course, difficult, if not impossible, to intellectualize at any length about the enforcement of discipline.) Before World War II, the United States professional military had a schooling which supplied little realistic orientation except to emphasize a simple mechanical version of ultimate civilian supremacy. However, even before the outbreak of World War II, slowly and painfully important sectors of the military elite had to reorient themselves on these matters. Reorientation came about as a result of the realities of the war. Of course, much of the crucial work merely devolved upon lowerrank staff officers and technical specialists, with the "top military cadre" not fully in sympathy.

In the absence of institutional indoctrination for these tasks, impressive indeed is the extent to which self-indoctrination succeeded in producing the number of officers capable of functioning in these areas. Nevertheless, the military establishment continues to be characterized by deep inner tensions because of its new responsibilities and because of the absence of a sufficiently large cadre of top officers sensitized to deal effectively with its broad administrative and political tasks.

Before World War II, whatever training and indoctrination existed for handling the complexities of civil-military relations and political tasks was primarily a self-generated mission. Some deviant career officers were not only sensitive to the emerging problems within the military establishment, but many of these officers sought to indoctrinate themselves about emerging problems of civilmilitary relations and of the political aspects of military operations. They often accepted 
specialized assignments of a quasi-political nature or those involving communications skills which supplied relevant opportunities for indoctrination and training. (These assignments included military attaché, foreignlanguage officer, intelligence officer, and public relations.) Voluntary acceptance or pursuit of these assignments represented genuine efforts at self-indoctrination and thereby selected out for training those who felt inclined and had potentials for growth. In the United States especially, before 1939, these assignments had relatively low prestige. In fact, they were seen as interfering with one's career, and therefore they were avoided by all except those who had suffcient foresight to see their high relevance. For many, these assignments did involve risk and short-term disadvantages. However, the results of such assignments in crucial cases were just the contrary. They assisted officers in entering the very top of the military elite, since they did, in fact, represent realistic indoctrination for emerging tasks.

Since the end of World War II, at all levels of the military establishment institutional indoctrination encompasses much wider perspectives-social and political. Although much of the new indoctrination appears to be oriented to the broader problems of the military establishment-internal and extemal-it is very much an open question as to what the consequences are likely to be for civil-military relations in a democratic society.

Ideological indoctrination is now designed to eliminate the civilian contempt for the "military mind." The "military mind" has been charged with a lack of inventiveness and traditionalism. The new indoctrination stresses initiative and continuous innovation. This is appropriate for the career motives of the new recruits and is important in creating conditions for overcoming bureaucratic inertia. The "military mind" has been charged with an inclination toward ultra-nationalism and ethnocentrism. Professional soldiers are being taught to de-emphasize ethnocentric thinking, since ethnocentrism is detrimental to national and military policy. The "military mind" has been charged as being disciplinarian. The new indoctrination seeks to deal with human factors in combat and in large-scale organization in a manner similar to contemporary thought on human relations in industry. In short, the new indoctrination is designed to supply the professional soldier with an opinion on all political, social, and economic subjects which he feels obliged to have as a result of his new role.

The new "intellectualism" is a critical capacity and a critical orientation. The military officer must be realistic, and he must review the shortcomings of the past and contemporary record of political-military relations. Will the growth of critical capacities be destructive, or will it be productive of new solutions? The consequence could be a growth in hostility toward past arrangements, in particular toward past political leadership of the military establishment and toward the dogmas of civilian supremacy. The military profession runs the risk of confusing its technical competency with intellectual background. As a result, it could become critical and negative toward the military bureaucracy and toward civilian political leadership in the same way that Joseph Schumpeter speaks of the universitytrained specialist becoming-critical of the economic system. In the United States at least, such hostility is hardly likely to lead to open disaffectation but more to passive resentment and bitterness.

In the long run, under either the democratic or the totalitarian model, the military establishment cannot be controlled and still remain effective by civilianizing it. Despite the growth of the logistical dimensions of 
warfare, the professional soldier is, in the last analysis, a military commander and not a business or organizational administrator. The democratic elite model of civilian supremacy must proceed on the assumption that the functions of the professional military are to command soldiers into battle. There is no reason to believe that the characteristics of the ideal professional soldier as a military commander are compatible with the ideal professional soldier as an object of civilian control, although the differences seem to be growing less and less as the automation of war continues. The quality of political control of the professional soldier is not to be judged by examining those aspects of the military establishment which are most civilian but rather those which are least civilian. Here the willingness to submit to civilian control, rather than the actuality of civilian control, is most crucial.

There is no reason to believe, in a democratic society, that the military can be controlled by offering them the conditions of employment found in civilian society. In the long run, civilian establishments would draw off all the best talent, especially in a business-dominated society. To achieve the objectives of the democratic elite model, it is necessary to maintain and build on the differentiation between civilian and military roles. A democratic society must accord the professional soldier a position based on his skill and on his special code of honor. He must be integrated because his fundamental differentiation is recognized. Under these circumstances, standards of behavior can be established and political directives enforced. The current drift toward the destruction of the differentiation of the military from the civilian cannot produce genuine similarity but runs the risk of creating new forms of hostility and unanticipated militarism.

\section{RE F E R E N C E S}

1. Boulding, Kenneth. Conflict Resolution, Vol. I, No. 2 (1957), in press.

2. Chorley, Katherine. Armies and the Art of Revolution. London: Faber \& Faber, 1943.

3. Coser, Lewis. The Functions of Social Confict. Glencoe, IIl.: Free Press, 1956.

4. Huntington, Samuel P. "Civilian Control of the Military: A Theoretical Statement." In Eulau Heinz, Elderseveld, Samuti, and Janowitz, Morris (eds.), Political Behavior: A Reader in Theory and Research, pp. 380-85. Glencoe, Ill.: Free Press, 1956.

5. Janowitz, Morris. The Professional Soldier and Political Power: A Theoretical Orientation and Selected Hypotheses. University of Michigan: Bureau of Government, Institute of Public Administration, 1953.

6. Lasswell, Harold D. World Politics and Personal Insecurity. Glencoe, Ill.: Free Press, 1950.

7. - - . "The Garrison State," American Journal of Sociology, January, 1941.

8. Marshali, S. L. A. Men against Fire: The Problem of Battle Command in Future War. Washington: Infantry Journal, 1947.

9. Moore, Barrington, Jr. "Sociological Theory and Contemporary Politics," American Journal of Sociology, September, 1955, pp. 107-15.

10. Simmel, Georg. Conflict. Translated by Kurt H. Wolff. Glencoe, Ill.: Free Press, 1955.

11. Speien, Hans. War and the Social Order: Papers in Political Sociology. New York: G. W. Stewart, 1952.

12. VAGTS, Alfred. The History of Militarism. New York: W. W. Norton \& Co., 1937.

13. Wright, Quincy. A Study of War. Chicagn: University of Chicago Press, 1942. 